\title{
A circular economy model for ethanol and alcohol-based hand sanitizer from sweet potato waste in the context of COVID-19
}

Caroline Trevisan Weber ${ }^{1}$, Lucas Ranzan¹, Luciano Luís Menz Liesegang1, Luciane Ferreira Trierweiler ${ }^{1}$, Jorge Otávio Trierweiler ${ }^{1}$

Group of Intensification, Modeling, Simulation, Control, and Optimization of Processes - GIMSCOP, Department of Chemical Engineering, Federal University of Rio Grande do Sul - UFRGS, Porto Alegre, RS, Brazil.

How to cite: Weber, C.T., Ranzan, L., Liesegang, L.L.M. et al. (2020), “A circular economy model for ethanol and alcohol-based hand sanitizer from sweet potato waste in the context of COVID-19", Brazilian Journal of Operations \& Production Management, Vol. 17, No. 03, e20201025. https://doi.org/10.14488/10.14488/BJOPM.2020.028

\section{ABSTRACT}

Goal: The goal of the present work is to analyze the techno-economic viability of a biorefinery to generate ethanol and alcohol-based hand sanitizer from sweet potato waste within the concept of a circular economy.

Design / Methodology / Approach: A survey of expenses for a 1000 L.day ${ }^{-1}$ distilled plant was carried out, and five different market scenarios were evaluated, varying the rate of production of each product.

Results: Results show that the higher the production of the hand sanitizer, the more lucrative the scenarios are. The economic breakeven point occurs when the percentage of the alcohol-based hand sanitizer production is equal to $34 \%$. However, the project becomes economically attractive from the production rate of $39 \%$. The scenario for $80 \%$ of alcohol-based hand sanitizer production resulted in NPV of US\$ $913,140.92$, IRR of $64 \%$, with a discounted payback of 0.72 year.

Limitations of the investigation: It was considered that all the production was sold, which is in line with the current market demand. However, if the market slows down, the sales and the revenue obtained may be lower.

Practical implications: The production of hand sanitizer from sweet potato waste is an opportunity to meet the market needs in scenarios such as the COVID-19 pandemic. Besides, the proposed biorefinery promotes the development of the circular economy through waste minimization.

Originality / Value: No studies about the production of ethanol and alcohol-based hand sanitizer from sweet potato waste in an integrated way and the simulation of different real market scenarios were found.

Keywords: Circular economy; Sweet Potato; Food Waste; Ethanol; Alcohol-Based Hand Sanitizer; COVID-19.

\section{INTRODUCTION}

In the linear model of production, raw materials are extracted, processed, consumed, and discarded (Hartley et al., 2020). The planet's natural resources (water, energy, raw material) are sparse. Environmental deterioration is an intrinsic problem linked with the linear economy (Kapoor et al., 2020). With a world's population expected to reach 9.7 billion in 2050, the

Financial support: Coordenação de Aperfeiçoamento de Pessoal de Nível Superior (CAPES)

Conflict of interest: The authors have no conflict of interest to declare.

Corresponding author: caroltw@enq.ufrgs.br

Received: 30 June 2020.

Accepted: 26 July 2020.

Editor: Fernando Oliveira de Araujo and Chrystyane Abreu 
current industrial linear model is no longer acceptable (Ellen MacArthur Foundation, 2013). Since the circular economy can reduce material and human footprint by inserting systemic solutions, this model has risen as a cleaner alternative to linear systems (Fux, 2019). A circular economy focuses on the optimal use of resources, e.g., via waste minimization, contributing to environmental protection and providing socio-economic benefits (Morseletto, 2020).

Waste amounts are growing with the increase in population (de Sadeleer et al., 2020). Food is lost or wasted at distinct steps of the supply chain (Patra et al., 2020). Nearly 1.3 billion tons of foods are wasted globally (Food and Agriculture Organization of the United Nations, 2019), causing 10\% of greenhouse gas emissions (Intergovernmental Panel on Climate Change, 2019). Brazil is one of the major producers of commodities, producing huge quantities of waste (Forster-Carneiro et al., 2013). Reducing residual food is an essential way to lower the costs of production and contribute to environmental sustainability (Patra et al., 2020). Waste is a renewable resource and a crucial feedstock in the context of the bio-based circular economy (Mohan et al., 2019). Based on this, appear the biorefinery, which is a sustainable system that generates different products from biomass feedstocks through conversion technologies. With the significance of addressing environmental, social, and economic aspects of the industry, biorefinery plays a crucial role for the achievement of a circular economy (Figure 1) (Ubando et al., 2020).

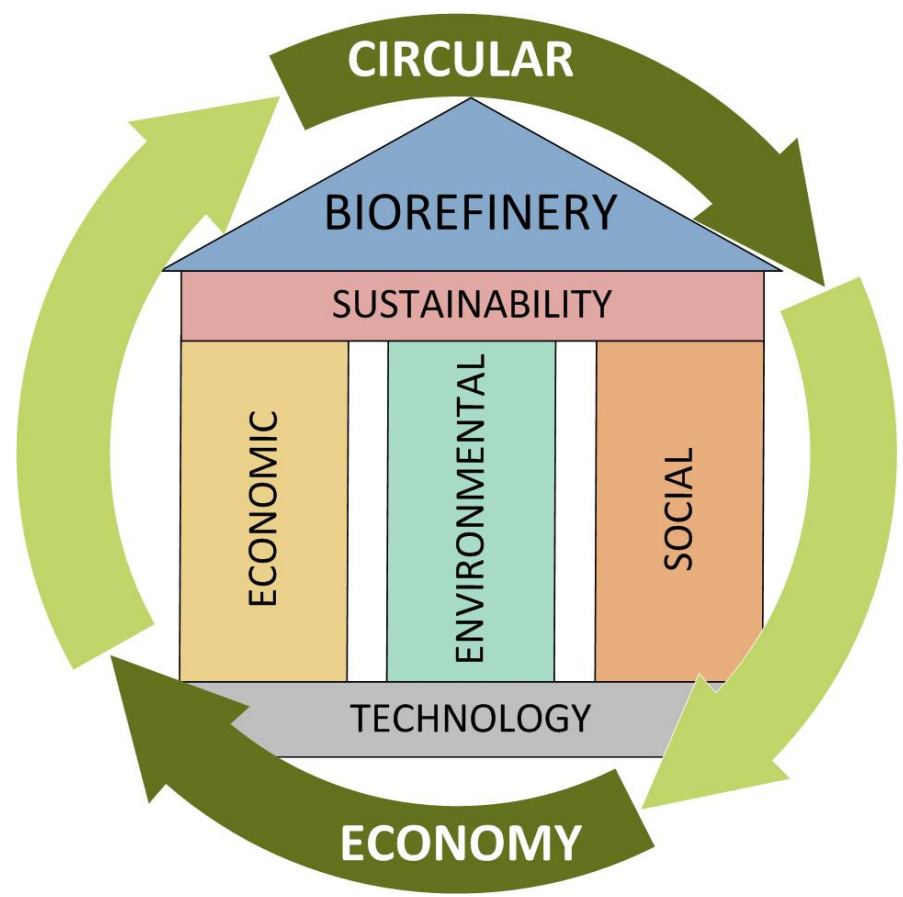

Figure 1. Strategic pillars of biorefinery for the realization of a circular economy Source: The authors themselves

Although the circular economy remains far from being a global reality, crisis scenarios can accelerate innovations in the sector. The worldwide pandemic that started in 2020 due to the spread of a coronavirus can be one of those driving forces (Corrêa and Corrêa, 2020). With the advance of COVID-19, the consumption and demand of prevention products such as hand sanitizers has increased, which had led to a crisis in these products at all levels (Jairoun et al., 2020), triggering a race to produce alcohol antiseptic gel. Initiatives aimed at proposing alternative methods of manufacturing alcohol-based hand sanitizer, including the use of different sources of ethanol (Melo, 2020). Agricultural and food residues are appealing raw materials for the conversion into valuable bioproducts, such as biofuels (Ng et al., 2020). Sweet potato (Ipomoea batatas) appears as a prosperous substrate for bioethanol manufacturing, as it presents a high yield in starch per cultivated area (Lareo and Ferrari, 2019). Brazil is the 
$16^{\text {th }}$ largest producer of sweet potato in the world (Instituto Brasileiro de Geografia e Estatistica, 2014; Food and Agriculture Organization of the United Nations, 2017). For tubers, the global quantitative food wastage is $45 \% / y e a r$ (Food and Agriculture Organization of the United Nations, 2019), totaling an annual waste of circa 350,000 tons of sweet potato in Brazil. Prior studies in our research group (GIMSCOP) have developed and enhanced the process of ethanol production from sweet potato waste (Masiero et al., 2014; Risso, 2014; Schweinberger et al., 2019a; Schweinberger et al., 2016). The production of bioethanol from biowaste contributes to reducing greenhouse emissions. Also, it leads to the evolution of new business opportunities across the food and agriculture sectors (Weber et al., 2020a).

The necessity of increasing the circularity of the industrial sector to convey finite resources availability and climate issues has stimulated the progress of food waste biorefineries. However, for the success of green industrial processes centered on the food waste valorization, critical aspects such as the analysis of their techno-economic potential need to be considered (Caldeira et al., 2020). Also, changing from a linear to a circular economy in the agri-food sector demand new business models (Donner et al., 2020). In this circumstance, given the grand productivity of sweet potato in Brazil and the market demand for alcohol-based hand sanitizer, there is an excellent opportunity to valorize this waste raw material and meet the market needs. Therefore, the goal of this work is to evaluate the technoeconomic viability of a biorefinery from sweet potato waste to produce ethanol and alcoholbased hand sanitizer within the concept of a circular economy in the context of COVID-19.

\section{METHOD}

The sweet potato used for ethanol production is the cultivar with light yellow peel and pulp. Rotting sweet potatoes were obtained in local fairs (Schweinberger et al., 2019a).

The ethanol and alcohol-based hand sanitizer production processes are exhibited in Figure 2. The sweet potato was cleaned, diced, steamed up to $76^{\circ} \mathrm{C}$, cooled and crushed. Then, the antibiotic, the enzymes, and the yeast were added. A buffer solution is added to adjust $\mathrm{pH}$ to $\mathrm{pH}$ 4. The mash was cultivated in an orbital shaker at $34^{\circ} \mathrm{C}$ for $19 \mathrm{~h}$. After, the fermented mash was subjected to distillation. Saccharomyces cerevisiae Angel Thermal Resistance Alcohol Yeast was supplied by LNF Latin America. The hydrolysis enzyme was Stargen 002, a commercial mixture of alpha-amylase and glucoamylase of the Genencor brand manufactured by DuPont. Pectinex Ultra AFP, provided by LNF Latin America, is a pectinase enzyme employed to decrease the medium viscosity. Tetracycline hydrochloride (3.4 g.L $\left.\mathrm{L}^{-1}\right)$ was the antibiotic agent added. The theoretic ethanol production and the fermentation experimental yield were calculated as in Schweinberger et al. (2019b).

The alcohol-based hand sanitizer production can be described as a simple batch mixture, but it has some peculiarities. The distilled ethanol is combined with three other ingredients: (i) a carbomer, commercial Carbopol 980, responsible for the increase in viscosity and gelification; (ii) a base, triethanolamine, responsible for the neutralization of the dispersion (the carbomer only achieve maximum viscosity between pH 6.0 and 7.0), and (iii) purified water. Following international regulations and published studies (Kampf, 2018), the weight of each ingredient is adjusted, so the final product has $70 \%\left(\mathrm{w} . \mathrm{w}^{-1}\right)$ of ethanol. Recipes may vary the concentration of carbomer and neutralizer, depending on the desired consistency of the gel, usually ranging from $0.5-1.5 \%\left(w^{-1} \mathrm{w}^{-1}\right)$ of carbomer and the needed amount of triethanolamine to neutralize the final mixture. As the $\mathrm{pH}$ is very influential in the product viscosity, the operator can use the addition of triethanolamine to fine-tune the process. The carbomer is not easily mixed with water/ethanol, especially after gelification. To facilitate the process, in each batch, the carbomer is previously hydrated with hot water for 8-10 hours. The carbomer-water mixture is then vigorously stirred with motorized paddles in a mixture reactor, and the ethanol is added. Once the product is fairly mixed, and no carbomer can be seen dry or clumped, triethanolamine is added, and the $\mathrm{pH}$, as well as the visual appearance of the product, is controlled until the wanted viscosity is reached. Viscosity and spreading tests are conducted to ensure quality control, as well as periodic ethanol concentration tests. 


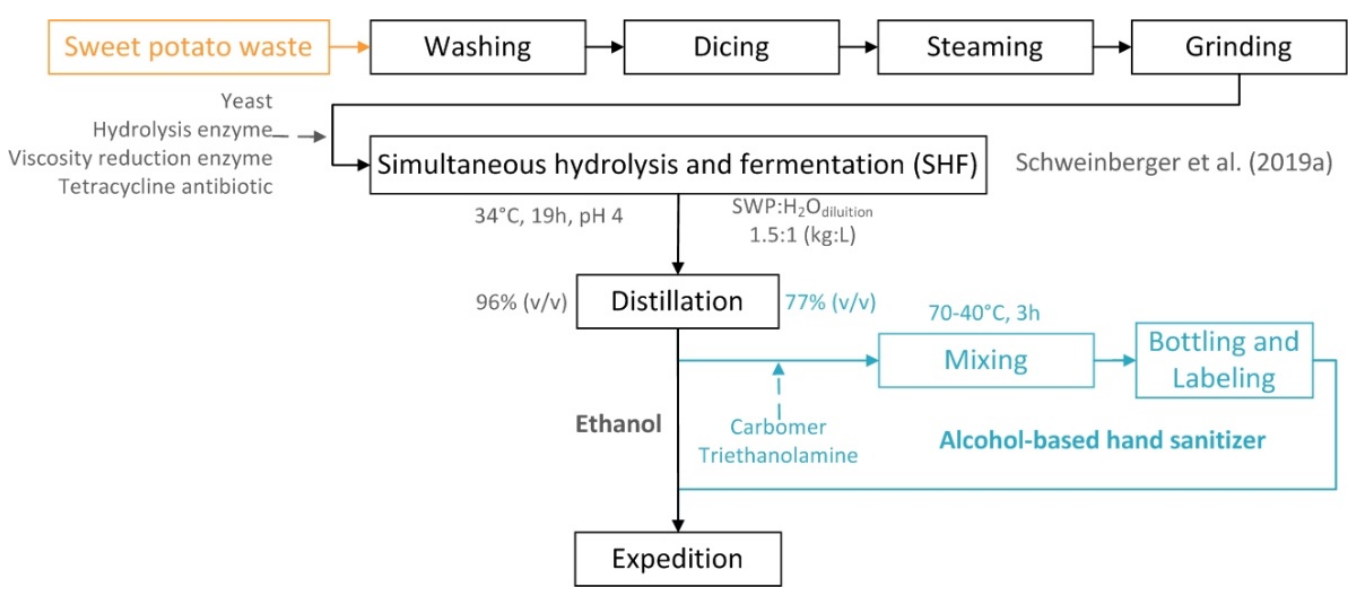

Figure 2. Ethanol and alcohol-based hand sanitizer production processes

Source: The authors themselves

The costs of inputs, which were described based on consultation with sellers (Weber et al., 2018), are shown in Figure 3. The amount of inputs concerning a 1000 L.day $^{-1}$ distilled production plant is shown in Chart 1.

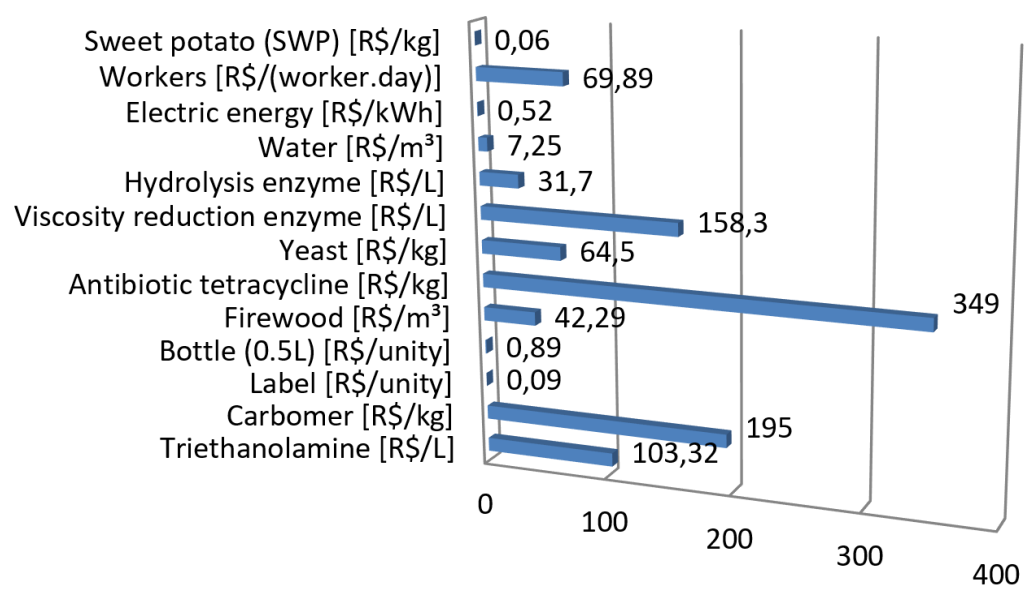

Figure 3. Cost of inputs to ethanol and alcohol-based hand sanitizer production Source: The authors themselves

Chart 1. The daily amount of inputs to ethanol and alcohol-based hand sanitizer production

\begin{tabular}{|c|c|c|}
\hline Input & Ethanol & Hand Sanitizer \\
\hline Sweet potato (SWP) [kg] & 5701.6 & 5701.6 \\
\hline Workers [workers] & 3 & 5 \\
\hline Electric energy [kWh] & 128.3 & 140.02 \\
\hline Water $\left[\mathrm{m}^{3}\right]$ & 29.58 & 29.58 \\
\hline Hydrolysis enzyme [L/kg SWP] & 0.001 & 0.001 \\
\hline Viscosity reduction enzyme [L/kg SWP] & 0.0001 & 0.0001 \\
\hline Yeast [kg/kg SWP] & 0.0033 & 0.0033 \\
\hline Antibiotic tetracycline [kg/kg SWP] & 0.0003 & 0.0003 \\
\hline Firewood $\left[\mathrm{m}^{3}\right]$ & 2.2 & 2.2 \\
\hline Bottle $(0.5 \mathrm{~L})$ [unity/L sanitizer] & - & 2 \\
\hline Label [unity/L sanitizer] & - & 2 \\
\hline Carbomer [kg/L sanitizer] & - & 0.00245 \\
\hline Triethanolamine [ L/L sanitizer] & - & 0.00004 \\
\hline
\end{tabular}

Source: The authors themselves 
The sweet potato cost was calculated considering the agricultural production costs.

Brazil's national minimum salary in 2020 was considered for the cost of workers, i.e., $\mathrm{R} \$ 1045.00$ per month, with an additional of $33.77 \%$ due to labor benefits. 20 workdays per month were assumed, already considering scheduled shutdowns for machine maintenance. As the mixing and the bottling and labeling require responsible person for each process, the hand sanitizer process requires two more workers than the ethanol production process.

The equipment energy consumption gave the costs of electric energy. Sweet potatoes washing, mash preparation, and the steam generation, all impact on water costs.

Enzymes and yeast are used in the process of simultaneous hydrolysis and fermentation (SHF) to perform hydrolysis of the sweet potato starch and to reduce the viscosity of the medium. Tetracycline is used to prevent bacterial contamination.

Eucalyptus firewood was used to provide thermal energy for the sweet potato heating process, the distillation process, and the heating of the mixing tank. As the proposal is to use the same factory for producing ethanol and alcohol-based hand sanitizer, the cost of thermal energy was considered the same for both products.

Distillation was conducted up to $96 \%\left(v \cdot v^{-1}\right)$ and $77 \%\left(v \cdot v^{-1}\right)\left(\right.$ or $\left.70 \%\left(w \cdot w^{-1}\right)\right)$ for fuel ethanol and for use in the formulation of the hand sanitizer, respectively. The $1000 \mathrm{~L}$ ethanol plant can produce $1342 \mathrm{~L}$ of alcohol-based hand sanitizer daily. Alcohol-based hand sanitizer was bottled in plastic flasks with a volume of $0.5 \mathrm{~L}$. So, for the production of $1342 \mathrm{~L}$ of hand sanitizer, 2684 plastic bottles are needed per day.

Carbopol is a cross-linked polyacrylic acid polymer used as the thickening and gelling agent. Added to the ethanol-water solution, it increases the viscosity and stability of the product, being responsible for the essential 'gel' characteristic of the sanitizer. The dispersion must be neutralized to achieve maximum viscosity, between $\mathrm{pH} 6.0$ and 7.0. For pharmaceutical uses, triethanolamine is often the chosen neutralizing agent and is the one recommended by ANVISA in topical applications (Agência Nacional de Vigilância Sanitária, 2012).

All the costs are in line with the prices provided by sellers.

Tributary taxes for the hand sanitizer was $48.33 \%$, and $1.44 \mathrm{R} \$ / \mathrm{L}$ to fuel ethanol (Fecombustíveis, 2019).

The expected primary investment is $R \$ 629,650.00$, being $100 \%$ financed with an interest rate of $8 \%$ per annum, a grace period in the first year, and a payment term of 5 years.

Working capital of $\mathrm{R} \$ 160,000.00$ was considered.

The cash flow was calculated over 10 years, considering the building of the distillery in the year before the first.

A work journey of 8 hours/day (40 hours/week) was considered.

Depreciation expenses were calculated following the Federal Revenue Regulation RFB n. 1700 (Receita Federal, 2017).

Also, maintenance costs were considered, beginning at $1 \%$ in the first year and increasing $1 \%$ per year for the 10 years of operation.

As ethanol and alcohol-based hand sanitizer use the same facility, the percentage of production of each product can be changed based on the market needs. Therefore, five distinct scenarios of production were assessed. In all scenarios, it was estimated that $20 \%$ of ethanol production would be used for domestic consumption. The percentage production of ethanol and alcohol-based hand sanitizer destined for sale in each case is as follows:

- Scenario I: $80 \%$ ethanol;

- Scenario II: $60 \%$ ethanol; $20 \%$ alcohol-based hand sanitizer;

- Scenario III: $40 \%$ ethanol; $40 \%$ alcohol-based hand sanitizer;

- Scenario IV: $20 \%$ ethanol; $60 \%$ alcohol-based hand sanitizer;

- Scenario V: $80 \%$ alcohol-based hand sanitizer.

The revenue is the result of the sale of ethanol and alcohol-based hand sanitizer. It was considered that all the production was sold. 
The economic indicators Net Present Value (NPV), Internal Rate of Return (IRR), and discounted payback were calculated for the investment analysis.

\section{RESULTS AND DISCUSSION}

The total sugar content of the sweet potato used was $26.93 \pm 0.86 \%$, and the experimental cultivation yield was 93.91\% (Schweinberger et al., 2019a; Weber et al., 2020b). Hence, for the economic evaluation, a sweet potato with $30 \%$ of total sugar was assumed as a reference, and yields of $95 \%$ were assumed for both fermentation and distillation processes.

The inputs costs for the production of ethanol and alcohol-based hand sanitizer in a 1000 L.day $^{-1}$ distilled production plant is shown in Chart 2. The percentage of contribution of each input for both products is shown in Figure 4. The values were calculated in Brazilian Real $(\mathrm{R} \$)$, and after converted to United States Dollar (US\$). The conversion rate adopted was 5.37 R\$/US\$ (Banco Central do Brasil, 2020).

Chart 2. The total daily costs of inputs to ethanol and alcohol-based hand sanitizer production

\begin{tabular}{|ccccc|}
\hline \multirow{2}{*}{ Input } & \multicolumn{2}{c}{ Ethanol } & \multicolumn{2}{c|}{ Alcohol-based hand sanitizer } \\
\cline { 2 - 5 } & $\mathbf{R} \$$ & US\$* & R\$ & US\$* \\
\hline Sweet potato & 354.41 & 66.00 & 354.41 & 66.00 \\
\hline Workers & 209.68 & 39.05 & 349.47 & 65.08 \\
\hline Electric energy & 66.08 & 12.31 & 72.12 & 13.43 \\
\hline Water & 214.46 & 39.94 & 214.46 & 39.94 \\
\hline Hydrolysis enzyme & 180.74 & 33.66 & 180.74 & 33.66 \\
\hline Viscosity reduction enzyme & 90.26 & 16.81 & 90.26 & 16.81 \\
\hline Yeast & 1.213 .59 & 225.99 & 1.213 .59 & 225.99 \\
\hline Antibiotic tetracycline & 563.73 & 104.98 & 563.73 & 104.98 \\
\hline Firewood & 93.04 & 17.33 & 93.04 & 17.33 \\
\hline Bottle $(0.5$ L) & - & - & 2.390 .42 & 445.14 \\
\hline Label & - & - & 241.73 & 45.01 \\
\hline Carbomer & - & - & 640.97 & 119.36 \\
\hline Triethanolamine & - & - & 6.01 & 1.12 \\
\hline Total & $\mathrm{R} \$ 2985.98$ & $\mathrm{US} \$ 556.05$ & $\mathrm{R} \$ 6410.92$ & $\mathrm{US} \$ 1193.84$ \\
\hline
\end{tabular}

*US\$1.00 = 5.37 R\$ (Banco Central do Brasil, 2020)

Source: The authors themselves

\section{Ethanol}

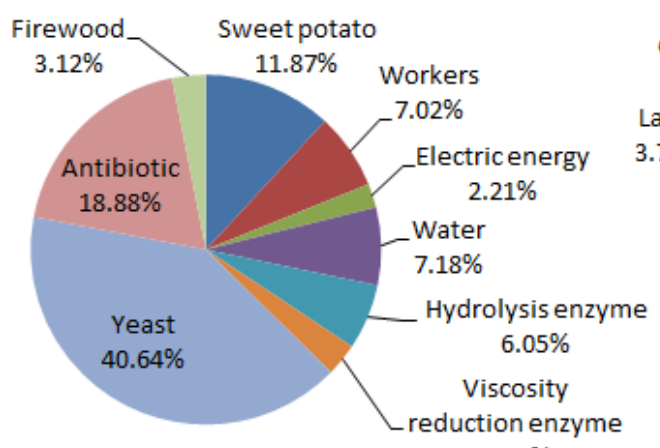

$3.02 \%$

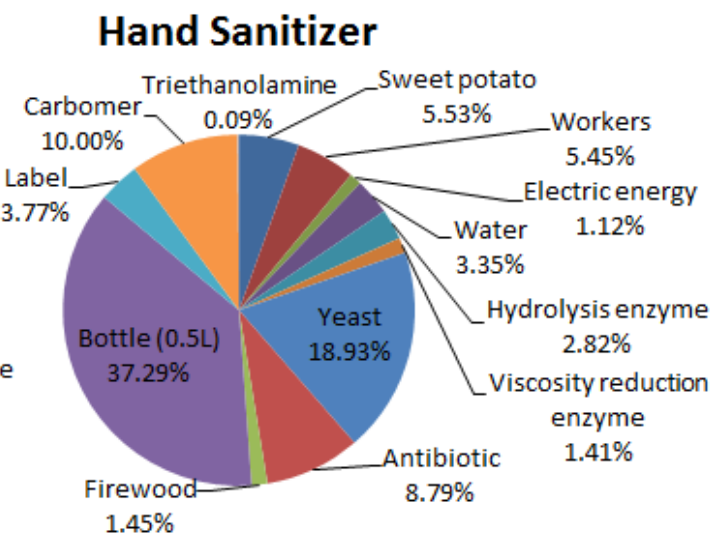

Figure 4. Percentage of the contribution of each input to ethanol and alcohol-based hand sanitizer production

Source: The authors themselves 
The total cost of inputs estimated to produce alcohol-based hand sanitizer from sweet potato was US\$1193.84 per day. This value is higher than the total cost of inputs estimated to produce ethanol, which totaled US $\$ 556.05$ per day. This difference occurs mainly because of the costs concerning the bottling process. Besides, as to the production of alcohol-based hand sanitizer, two additional workers are necessary; labor costs represent another relevant factor to the variation in the products' total cost of inputs.

Considering the contribution of each input in the total of costs, it is perceived that to the alcohol-based hand sanitizer production process, the highest cost was with the plastic bottles, representing $37.29 \%$ of the total costs of inputs. An option to reduce this cost is to change the volume of bottles used to a bigger model, reducing; thus, the number of bottles needed and consequently reducing the costs with this input. The second higher input's cost involved in the alcohol-based hand sanitizer production (18.93\%), and the first in the ethanol production $(40.64 \%)$, was with yeast. Schweinberger recycled yeast cells 11 times, lowering the costs by $87 \%$ (Schweinberger et al., 2016). So, the cost of yeast can be reduced if the recycling of yeast cells is considered.

The same equipment and the same factory are used for the production of ethanol and alcohol-based hand sanitizer from sweet potato. This fact allows the modification of each product production percentage according to market demands. Therefore, results considering five scenarios were estimated.

The basis of the Scenario I is the manufacture and utilization of biofuels, such as bioethanol. It can happen when the price of fossil fuels is too high, or when policies encourage large production of biofuels. In Scenario II, the beginning of the production of alcohol-based hand sanitizer is considered, with the entrance of this product in the market. Scenario III shows a situation where the production of each product for sale is the same. A heated market for the alcohol-based hand sanitizer, with a minor focus on biofuels, is showed in Scenario IV. In Scenario $V$, ethanol is produced merely for internal use. At the same time, the whole production is focused on the alcohol-based hand sanitizer. This scenario shows the current situation caused by the COVID-19 pandemic situation, in which market demand increased by $6500 \%$, and many companies mobilized to produce alcohol-based hand sanitizer (Gratão, 2020).

Discounted payback, IRR, and NPV were the economic indicators used to estimate the investment analysis results for each scenario. For this calculation, 10 years of operation were considered. The MARR (Minimum Acceptable Rate of Return) was equal to 10\%.

The prices of fuel ethanol and alcohol-based hand sanitizer were determined according to the mean market prices. Average prices of $R \$ 3.65$ (US\$ 0.68) and $R \$ 13.00$ (US\$2.42) for ethanol and alcohol-based hand sanitizer, respectively, were assumed for the revenue calculation. It was considered the sale of the total production for both products. The investment analysis results are shown in Chart 3.

Chart 3. Investment analysis indicators for the five evaluated scenarios in 10 years of operation

\begin{tabular}{|ccccc|}
\hline Scenario & NPV (R) & NPV(US\$)* & IRR (\%) & Payback (year) \\
\hline Scenario I & $\mathrm{R} \$-3,604,610.84$ & US\$ $-671,249.69$ & $<0 \%$ & - \\
\hline Scenario II & $\mathrm{R} \$-1,477,566.45$ & US\$ $-275,152.04$ & $<0 \%$ & - \\
\hline Scenario III & $\mathrm{R} \$ 649,477.95$ & US\$ $120,945.61$ & $12 \%$ & 5.61 \\
\hline Scenario IV & $\mathrm{R} \$ 2,776,522.35$ & US\$ $517,043.27$ & $42 \%$ & 1.44 \\
\hline Scenario V & $\mathrm{R} \$ 4,903,566.74$ & US\$ $913,140.92$ & $64 \%$ & 0.72 \\
\hline
\end{tabular}

*US\$1.00 = 5.37 R $\$$ (Banco Central do Brasil, 2020)

Source: The authors themselves

A project is considered economically feasible when the NPV value is higher than zero, and the IRR percentage is higher than the adopted MARR. So, between the economic scenarios studied, Scenarios III, IV, and V are the economically viable ones. Scenarios I and II presented 
negative IRR and NPV, indicating economic losses. Although ethanol is produced from waste, the manufacturing costs are still elevated, making the process economically impractical at a large scale (Chohan et al., 2020). It happens in the Scenario I, showing that the costs are more significant than the revenue when only ethanol is produced. The alcohol-based hand sanitizer started being produced in Scenario II, presenting a little better result, but still being an economically unfeasible scenario. The financial results start to be positive in Scenario III, where the percentage of production of each product is equal to $40 \%$. Scenario III and IV reach positive values in 5.61 and 1.44 years, respectively. This value is the discounted payback, i.e., the time for the investments to be fully recovered. The best scenario that showed the highest values of NPV (US\$913,140.92) and IRR (64\%) was the scenario V, what happens in 0.72 year, the shorter time to the investment to be returned. Therefore, the higher the production of alcohol-based hand sanitizer, the greater the project's financial results.

Considering the high fluctuation in the price of alcohol-based hand sanitizer during the pandemic of COVID-19, and seeking to know the breakeven point in the percentage of production of each product, Figure 5 was plotted. The price of the alcohol-based hand sanitizer ranged from $R \$ 13.00$ - 20.00 (US\$2.42 - 3.72) per liter and its percentage of production rate ranged from $25-80 \%$. Using Python software, the graphs of Figure 5 were plotted, and NPV and TIR were estimated. The plateau represents points with an IRR of less than $-50 \%$, which were disregarded in order not to pollute the graphs visually.
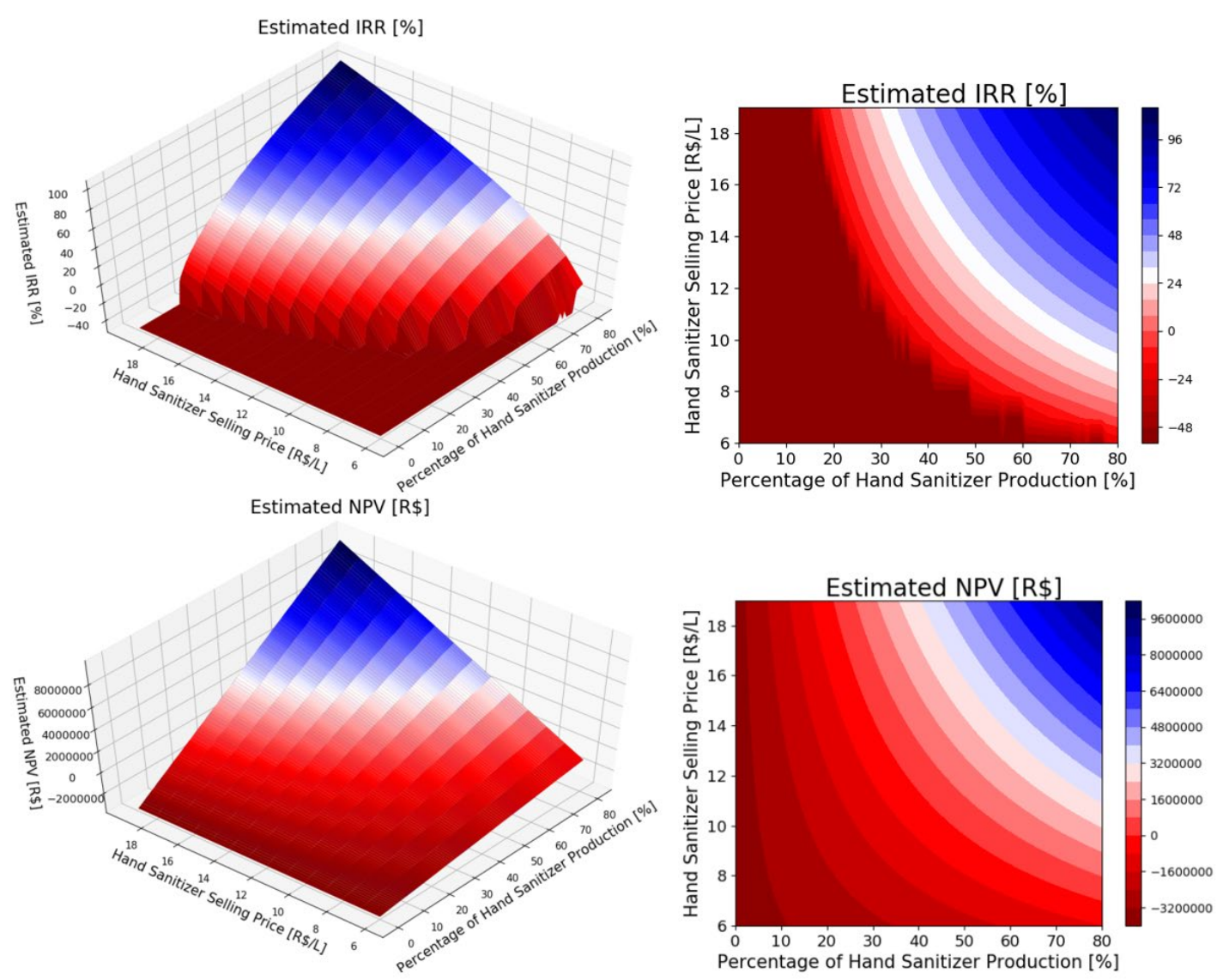

Figure 5. Sensitivity analysis of NPV and IRR versus the percentage of production and the price of alcohol-based hand sanitizer

Source: The authors themselves

Figure 5 shows that the higher the price and the higher the percentage of production of alcohol-based hand sanitizer, the better the financial results. Keeping the average price of alcohol-based hand sanitizer at $R \$ 13.00$ (US\$ 2.42) per liter, the sweet potato waste 
biorefinery starts to present positive economic results ( $N P V>0)$ when the production's percentage of this product is equal to $34 \%$. However, as the IRR $(0.23 \%)$ is lower than the MARR $(10 \%)$, it is not economically attractive. The project becomes attractive when the production of alcohol-based hand sanitizer reaches $39 \%$, presenting an IRR of $10.21 \%$, and an NPV of $\mathrm{R} \$ 543,125.73$ (US\$ 101.140,73). The best scenario would be the one with the highest production (80\%) and the highest price ( $\mathrm{R} \$ 20.00$ or US $\$ 3.72$ per liter) of the alcohol-based hand sanitizer, returning an NPV of R\$10,629,964.85 (US\$ 1.979.509,28) and an IRR of 111.37\%.

Advanced biorefineries are key elements to implement a sustainable bioeconomy (Dragone et al., 2020). However, not all biorefineries are financially feasible projects. A cassava waste biorefinery producing bioethanol, combined heat and power, and succinic acid, showed economic and environmental benefits (Padi and Chimphango, 2020). On the other hand, an algae-based biorefinery integrated with the production of palm oil was not financially viable (Abdul Hamid and Lim, 2019). Small scale production plants' development has high importance in countries as Brazil, allowing to add value to local substrates and to make the processes more economically attractive. Biomass valorization at a regional level is relevant for local cooperatives, contributing to the local sustainable development within a circular economy approach (Virgínio and Silva et al., 2018; Donner et al., 2020). Hence, the findings attained by the proposed biorefinery exhibit high potential for being a sustainable model through valorizing and processing sweet potato waste in products with higher value-added, then reaching the purposes of a circular economy.

\section{CONCLUSION}

The objective of evaluating the techno-economic viability of the production of ethanol and alcohol-based hand sanitizer from sweet potato waste was achieved, showing favorable results.

The total cost of inputs involved in the alcohol-based hand sanitizer production process reached US\$1193.84 per day. The highest cost was with the plastic bottles, representing $37.29 \%$ of the total costs of inputs. A solution to reduce this cost is to change the volume of bottles used to a bigger model, reducing; thus, the number of bottles needed and consequently reducing the costs.

Five different production scenarios were evaluated, altering the production of ethanol and alcohol-based hand sanitizer. The scenario with the highest production of alcohol-based hand sanitizer was the most profitable one. In contrast, the situations with higher production of ethanol showed negative economic results. The economic breakeven point occurs when the percentage of the alcohol-based hand sanitizer production is equal to $34 \%$. However, the project becomes economically attractive from the production rate of 39\%. The best scenario ( $80 \%$ alcohol-based hand sanitizer) gave NPV of US\$913,140.92, IRR of $64 \%$, and discounted payback of 0.72 year.

The production of $1342 \mathrm{~L}$ of alcohol-based hand sanitizer per day is relevant to help meet the immediate market needs in the face of the COVID-19 pandemic crisis. Also, the use of a source of alcohol from waste material contributes to reducing greenhouse gas emissions and savings of landfills costs, achieving then the goals of a circular bioeconomy.

For future works, it is suggested a study of the replacement of the carbomer for a more natural alternative in the hand sanitizer manufacturing, such as Amigum (Alban Muller, 2020b) or Amigel ${ }^{\circledR}$ (Alban Muller, 2020a).

\section{ACKNOWLEDGMENT}

This study was financed in part by the Coordenação de Aperfeiçoamento de Pessoal de Nível Superior - Brasil (CAPES) - Finance Code 001. The authors also would like to acknowledge support from the Universidade Federal do Rio Grande do Sul (UFRGS). 


\section{REFERENCES}

Abdul Hamid, N.N. and Lim, J.S. (2019), "Evaluation of processing route alternatives for accessing the integration of algae-based biorefinery with palm oil mill", Journal of Cleaner Production. Elsevier Ltd, Vol. 212, pp. 1282-99. http://dx.doi.org/10.1016/j.jclepro.2018.12.104.

Agência Nacional de Vigilância Sanitária - ANVISA (2012), Formulário Nacional da Farmacopeia Brasileira, $2^{a}$ ed. Revisão 02, Ministério da Saúde. Agência Nacional de Vigilância Sanitária, Brasília, p. 60.

Alban Muller (2020a), "Gelling agent and stabilizer - Amigel ${ }^{\circledR ", ~ a v a i l a b l e ~ a t: ~}$ https://pro.albanmuller.com/en/offre/gelling-agent-and-stabilizer/ (accessed 30 May 2020).

Alban Muller (2020b), "Gelling and stabilizing agent for supple texture - Amigum". available at: https://pro.albanmuller.com/en/offre/gelling-and-stabilizing-agent-for-supple-texture/ (accessed 30 May 2020).

Banco Central do Brasil (2020), “Exchange rate U.S. Dollar", available at: https://www.bcb.gov.br/ (accessed 26 May 2020).

Caldeira, C., Vlysidis, A., Fiore, G. et al. (2020), "Sustainability of food waste biorefinery: a review on valorisation pathways, techno-economic constraints, and environmental assessment", Bioresource Technology, Vol. 312, p. 123575. http://dx.doi.org/10.1016/j.biortech.2020.123575.

Chohan, N.A., Aruwajoye, G.S., Sewsynker-Sukai, Y. et al. (2020), "Valorisation of potato peel wastes for bioethanol production using simultaneous saccharification and fermentation: Process optimization and kinetic assessment", Renewable Energy, Vol. 146, pp. 1031-40. http://dx.doi.org/10.1016/j.renene.2019.07.042.

Corrêa, H.L. and Corrêa, D.G. (2020), "Could the COVID-19 pandemic crisis stimulate circular economy practices? A brief reflection", Brazilian Journal of health RE:view, Vol. 3, No. 2, pp. 3820-32. http://dx.doi.org/10.34119/bjhrv3n2-205.

de Sadeleer, I., Brattebø, H. and Callewaert, P. (2020), "Waste prevention, energy recovery or recycling Directions for household food waste management in light of circular economy policy", Resources, Conservation and Recycling, Vol. 160, p. 104908. http://dx.doi.org/10.1016/j.resconrec.2020.104908.

Donner, M., Gohier, R. and de Vries, H. (2020), "A new circular business model typology for creating value from agro-waste", Science of the Total Environment, Vol. 716, pp. 137065. http://dx.doi.org/10.1016/j.scitotenv.2020.137065.

Dragone, G., Kerssemakers, A.A.J., Driessen, J.L.S.P. et al. (2020), "Innovation and strategic orientations for the development of advanced biorefineries", Bioresource Technology, Vol. 302, p. 122847. http://dx.doi.org/10.1016/j.biortech.2020.122847.

Ellen MacArthur Foundation (2013), Towards the circular economy. Economic and business rationale for an accelerated transition, Isle of Wight England, available at: https://www.ellenmacarthurfoundation.org/assets/downloads/publications/Ellen-MacArthurFoundation-Towards-the-Circular-Economy-vol.1.pdf (accessed 26 May 2020).

Fecombustíveis (2019), Tributação. available at: http://www.fecombustiveis.org.br/revendedor/tributacao/ (accessed 7 October 2019).

Food and Agriculture Organization of the United Nations - FAO (2017), Statistics Division, available at: http://fenix.fao.org/faostat/beta/en/?\#rankings/countries_by_commodity (accessed 1 May 2017).

Food and Agriculture Organization of the United Nations - FAO (2019), Food Loss and Food Waste. available at: http://www.fao.org/food-loss-and-food-waste/en/ (accessed 25 September 2019).

Forster-Carneiro, T., Berni, M.D. Dorileo, I.L. et al. (2013), "Biorefinery study of availability of agriculture residues and wastes for integrated biorefineries in Brazil", Resources, Conservation and Recycling, Vol. 77, pp. 78-88. http://dx.doi.org/10.1016/j.resconrec.2013.05.007.

Fux, H. (2019), "What is the ideal scenario for circular economy to occur? A case study of the CircE project", Brazilian Journal of Operations \& Production Management, Vol. 16, No. 1, pp. 157-65. http://dx.doi.org/10.14488/bjopm.2019.v16.n1.a15.

Gratão, P. (2020), “Coronavírus: Empresas se mobilizam para produzir e doar álcool gel e máscaras para o SUS", Pequenas Empresas \& Grandes Negócios, 28 Mar, available at: https://revistapegn.globo.com/Impacto-social/noticia/2020/03/coronavirus-empresas-semobilizam-para-produzir-e-doar-alcool-gel-e-mascaras-para-o-sus.html (accessed: 11 June 2020). 
Hartley, K., van Santen, R. and Kirchherr, J. (2020), "Policies for transitioning towards a circular economy: Expectations from the European Union (EU)", Resources, Conservation and Recycling, Vol. 155, p. 104634. http://dx.doi.org/10.1016/j.resconrec.2019.104634.

Instituto Brasileiro de Geografia e Estatistica - IBGE (2014), Produção Agrícola Municipal - Culturas Temporárias e Permanentes. IBGE, Rio de Janeiro.

Intergovernmental Panel on Climate Change - IPCC (2019), Climate Change and Land. available at: https://www.ipcc.ch/srccl/ (accessed: 11 June 2020)

Jairoun, A. A., Al-Hemyari, S. S. and Shahwan, M. (2020), "The pandemic of COVID-19 and its implications for the purity and authenticity of alcohol-based hand sanitizers: The health risks associated with falsified sanitizers and recommendations for regulatory and public health bodies", Research in Social and Administrative Pharmacy, In Press, pp. 1-2. http://dx.doi.org/10.1016/j.sapharm.2020.04.014.

Kampf, G. (2018), "Efficacy of ethanol against viruses in hand disinfection", Journal of Hospital Infection, Vol. 98, No. 4, pp. 331-8. http://dx.doi.org/10.1016/j.jhin.2017.08.025.

Kapoor, R., Ghosh, P., Kumar, M. et al. (2020), "Valorization of agricultural waste for biogas based circular economy in India: A research outlook', Bioresource Technology. Elsevier, Vol. 304, p. 123036. http://dx.doi.org/10.1016/j.biortech.2020.123036.

Lareo, C. and Ferrari, M.D. (2019), "Sweet potato as a bioenergy crop for fuel ethanol production: perspectives and challenges", in Ray, R.C. and Ramachandran, S. (Eds.), Bioethanol production from food crops: sustainable sources, interventions, and challenges. Academic Press, Cambridge, pp. 115-48.

Masiero, S.S., Peretti, A., Trierweiler, L.F. et al. (2014), "Simultaneous cold hydrolysis and fermentation of fresh sweet potato", Biomass and Bioenergy. Elsevier Ltd, Vol. 70, pp. 174-83. http://dx.doi.org/10.1016/j.biombioe.2014.08.007.

Melo, A. (2020), “5 iniciativas que surpreenderam na prevenção contra o COVID-19”, Casa e Jardim, 19 Março, available at: https://revistacasaejardim.globo.com/Curiosidades/noticia/2020/03/5-iniciativas-quesurpreenderam-na-prevencao-contra-o-covid-19.html (accessed 26 May 2020).

Mohan, S.V., Dahiya, S., Amulya, K. et al. (2019), "Can circular bioeconomy be fueled by waste biorefineries - A closer look", Bioresource Technology Reports. Elsevier, Vol. 7, pp. 100277. http://dx.doi.org/10.1016/j.biteb.2019.100277

Morseletto, P. (2020), "Targets for a circular economy", Resources, Conservation and Recycling. http://dx.doi.org/10.1016/j.resconrec.2019.104553.

$\mathrm{Ng}$, H.S., Kee, P.E., Yim, H.S. et al. (2020), "Recent advances on the sustainable approaches for conversion and reutilization of food wastes to valuable bioproducts", Bioresource Technology. Elsevier, Vol. 302, No. 135, pp. 122889. http://dx.doi.org/10.1016/j.biortech.2020.122889.

Padi, R. K. and Chimphango, A. (2020), "Feasibility of commercial waste biorefineries for cassava starch industries: Techno-economic assessment", Bioresource Technology. Elsevier, Vol. 297, p. 122461. http://dx.doi.org/10.1016/j.biortech.2019.122461.

Patra, D., Leisnham, P.T., Tanui, C.K. et al. (2020), "Evaluation of global research trends in the area of food waste due to date labeling using a scientometrics approach", Food Control. Elsevier, Vol. 115, pp. 107307. http://dx.doi.org/10.1016/j.foodcont.2020.107307.

Receita Federal (2017), Instrução Normativa RFB n 1700, de 14 de Março de 2017. Diário Oficial da União. available at: $\quad$ http://normas.receita.fazenda.gov.br/sijut2consulta/link.action?idAto=81268\&visao=compilado (accessed 1 May 2017).

Risso, R. (2014), Etanol de batata-doce: otimização do pré-processamento da matéria-prima e da hidrólise enzimática, Dissertação de Mestrado, Universidade Federal do Rio Grande do Sul, Porto Alegre.

Schweinberger, C.M., Putti, T.R., Susin, G.B. et al. (2016), "Ethanol production from sweet potato: Effect of ripening, comparison of two heating methods, and cost analysis", Canadian Journal of Chemical Engineering, Vol. 94, pp. 716-24.

Schweinberger, C.M., Trierweiler, J.O. and Trierweiler, L.F. (2019a), "A simple equation for Total Reducing Sugars (TRS) estimation on sweet potato and ethanol yield potential", Brazilian Journal of Chemical Engineering, Vol. 36, No. 1, pp. 33-41. http://dx.doi.org/10.1590/0104-6632.20190361s20170404.

Schweinberger, C.M., Trierweiler, J.O. and Trierweiler, L.F. (2019b), "Preheating followed by simultaneous viscosity reduction, hydrolysis, and fermentation: Simplifying the Process of Ethanol Production from Sweet Potato", BioEnergy Research, Vol. 12, No. 1, pp. 94-102. http://dx.doi.org/10.1007/s12155-0189953-9. 
Ubando, A.T., Felix, C.B. and Chen, W.H. (2020), "Biorefineries in circular bioeconomy: A comprehensive review", Bioresource Technology, Vol. 299, pp. 1-13. http://dx.doi.org/10.1016/j.biortech.2019.122585.

Virgínio e Silva, J.O., Almeida, M.F., Alvim-Ferraz, M.C. et al. (2018), "Integrated production of biodiesel and bioethanol from sweet potato", Renewable Energy, Vol. 124, pp. 114-20. http://dx.doi.org/10.1016/j.renene.2017.07.052.

Weber, C.T., Casagrande, T., Candido, G. et al. (2020b), "Alternative process for production of sweet potato distilled beverage", Brazilian Archives of Biology and Technology, Vol.63: e20190181. http://dx.doi.org/10.1590/1678-4324-2020190181.

Weber, C.T., Trierweiler, L.F. and Trierweiler, J.O. (2020a), "Food waste biorefinery advocating circular economy: Bioethanol and distilled beverage from sweet potato", Journal of Cleaner Production, Vol. 268, http://dx.doi.org/10.1016/j.jclepro.2020.121788.

Weber, C.T., Trierweiler, L.F., Casagrande, T. et al. (2018), "Economic evaluation of sweet potato distilled beverage produced by alternative route", International Journal of Development and Sustainability, Vol. 7, No. 10 , pp. 2514-27.

Authors contributions: Caroline Trevisan Weber: Conceptualization, Data Curation, Formal analysis, Investigation, Methodology, Writing - Original Draft, Writing - Review \& Editing. Lucas Ranzan: Conceptualization, Data Curation, Methodology, Writing - Original Draft. Luciano Luís Menz Liesegang: Conceptualization, Data Curation, Methodology. Luciane Ferreira Trierweiler: Conceptualization, Funding acquisition, Methodology, Project administration, Supervision, Writing - Review \& Editing. Jorge Otávio Trierweiler: Conceptualization, Funding acquisition, Methodology, Project administration, Supervision, Writing - Review \& Editing. 